\title{
Motor Nerve Regulates Muscle Extracellular Matrix Proteoglycan Expression
}

\author{
Ricardo Fadic, Enrique Brandan, and Nibaldo C. Inestrosa \\ Molecular Neurobiology Unit, Department of Cell and Molecular Biology, Faculty of Biological Sciences and Faculty of \\ Medicine, Catholic University of Chile, Santiago, Chile
}

\begin{abstract}
Denervation of rat leg muscles caused a 2-3-fold increase in ${ }^{35} \mathrm{~S}$-sulfate and ${ }^{3} \mathrm{H}$-glucosamine incorporation into proteoglycans of the muscle extracellular matrix. The size of the proteoglycans and the glycosaminoglycan chain length and degree of sulfation were unchanged. Because the rate of degradation of proteoglycans was also unchanged by denervation, we infer that denervation increases proteoglycan synthesis. Muscle reinnervation restored the original rate of synthesis of proteoglycans. Paralysis of innervated muscle caused increased incorporation of sulfate comparable to that seen in denervation. Thus motor nerve activity appears to regulate the level of proteoglycans in the muscle extracellular matrix.
\end{abstract}

The extracellular matrix (ECM) provides a unique physical and functional boundary that specifies the properties of the normal assembly of the neuromuscular junction. Reinnervation of skeletal muscles is topographically specific as axons preferentially form new junctions at original synaptic sites (Sanes et al., 1978; Sanes, 1989). Skeletal muscle fibers regulate their susceptibility to synapse formation in accordance with their current state of innervation: nerves implanted in innervated muscles do not generally form synapses, while denervated muscles easily accept innervation (Grinell and Herrera, 1981). Therefore, a muscle fiber might respond to nerve section by changing its surface properties, thereby increasing its attractiveness for regenerating axons. Cell-membrane and ECM molecules have been suggested as mediators of these interactions (Covault and Sanes, 1985; Rieger et al., 1985; Chiu et al., 1986; Sanes et al., 1986).

Proteoglycans are ubiquitously present in the ECM (Hascall and Hascall, 1981), as well as in association with the plasma membrane of eukaryotic cells (Höök et al., 1984), where they appear to play a role in developmental interactions important for growth control, tissue morphogenesis, and cell differentiation (Ruoslathi, 1989). Recently, proteoglycans have also been implicated in the modulation of similar interactions in the nervous system. Heparan sulfate (HS) proteoglycans are associated with laminin-containing neurite-promoting factors (Lander et al., $1982,1985)$. In the CNS, HS proteoglycans may play important

\footnotetext{
Received Nov. 29, 1989; revised May 16, 1990; accepted June 26, 1990.

This work was supported by grants from DIUC (77/87), FONDECYT (437/ 88 ), and Stiftung Volkswagenwerk to N.C.I. and by grants from FONDECYT $(569 / 89)$ and IFS (A/1407-1) to E.B. R.F. was a Postdoctoral Fellow in Basic Sciences from the School of Medicine, Catholic University of Chile.

Correspondence should be addressed to Nibaldo C. Inestrosa, Department of Cell and Molecular Biology, Faculty of Biological Sciences and Faculty of Medicine, Catholic University of Chile, P.O. Box 114-D, Santiago, Chile.
}

Copyright (C) 1990 Society for Neuroscience $0270-6474 / 90 / 113516-08 \$ 03.00 / 0$ roles as evidenced by their involvement in neural-cell adhesionmolecule (N-CAM)-mediated adhesion of retinal neurons to each other and to an extracellular substrate (Cole et al., 1985, 1986). Also, an HS proteoglycan has been identified as a cellsurface receptor for purpurin, the chick neural retina adhesion molecule (Schubert et al., 1986; Berman et al., 1987).

In the PNS, it has been suggested that the HS proteoglycan is involved in axonal regeneration along laminin-rich pathways (Chiu et al., 1986) and in the guidance of axons to the original synaptic sites of denervated neuromuscular junctions (Sanes et al., 1986). A nerve-terminal-anchorage macromolecule isolated from the ECM of the Torpedo electric organ corresponds to a chondroitin sulfate (CS) proteoglycan (Carlson and Wight, 1987). Furthermore, a neural-surface HS proteoglycan is a functionally important component of the Schwann cell mitogen associated with dorsal root ganglion neurons (Ratner et al., 1988). Proteoglycans therefore seem to be important for neuronal cell adhesion and growth.

Work in our laboratory has shown that rat skeletal muscle synthesizes and incorporates HS, CS, and dermatan sulfate (DS) proteoglycans into the ECM (Brandan and Inestrosa, 1987a,b).

One of the most important influences of nerves on muscle is to maintain normal contractile activity, thus regulating the level of cell-surface molecules such as AChE (Lømo et al., 1985) and extrajunctional AChR (Lomo and Rosenthal, 1972; Reiness and Hall, 1977). Moreover, it has been reported that ncrvc-cvokcd muscle activity regulates the level of mRNA expression of different AChR subunits (Merlie et al., 1984; Shieh et al., 1987; Goldman et al., 1988). Because there is essentially no information about the regulation of the expression of the ECM proteoglycans, it is important to evaluate the role of innervation in this process.

Here, we report that denervation increases the expression of proteoglycans of muscle ECM. This effect is related to the contractile activity induced in muscle fibers by the nerve. To our knowledge, this is the first biochemical demonstration of changes in proteoglycans of skeletal muscle ECM following motor nerve section.

\section{Materials and Methods}

Materials. ${ }^{35} \mathrm{~S}-\mathrm{Na}_{2} \mathrm{SO}_{4}$ (carrier-free) and ${ }^{3} \mathrm{H}$-glucosamine $(30 \mathrm{Ci} / \mathrm{mmol})$ were obtained from New England Nuclear, Boston, MA. Chondroitinase ABC, DEAE-Sephacel, and Sepharose CL-4B and $-6 B$ were obtained from Sigma Chemicals, St. Louis, MO.

Animals and surgical procedures. For denervation, male SpragueDawley rats $(120 \mathrm{gm})$ were anesthetized with sodium pentobarbitone (35 $\mathrm{mg} / \mathrm{kg}$ body weight, i.p.), and a $1-\mathrm{cm}$ segment of the sciatic nerve was removed at the sciatic notch. For nerve regeneration experiments, muscles were denervated by crushing the sciatic nerve with a hemostat 
for $30 \mathrm{sec}$. We tested reinnervation using both muscle response to nerve stimulation and measurements of $\mathrm{AChE}$ activity (Fadic and Inestrosa, 1989).

Muscle paralysis. Muscles were paralyzed by tenotomy or by complete blockade of nerve conduction with repeated local application of TTX. Tenotomy was carried out by cutting the distal tendons of the tibialis anterior, extensor digitorum longus, and tendo achillis. Sciatic nerve conduction was blocked by a subperineural injection of TTX using a glass micropipette. Two $\mu$ g TTX in $2 \mu \mathrm{l}$ Ringer's solution was injected every second day (Pestronk et al., 1977). To determine whether paralysis was due to nerve blockade rather than denervation, the sciatic nerve was stimulated in situ proximal and distal to the injection site.

Labeling and isolation of muscle proteoglycans. Animals were injected intraperitoneally with $1 \mathrm{mCi}{ }^{35} \mathrm{~S}-\mathrm{Na}_{2} \mathrm{SO}_{4}$ (carrier-free) in $0.9 \% \mathrm{NaCl}$. Six hr after injection, the rats were killed and the leg muscles removed. A detergent-insoluble fraction enriched in ECM components was prepared by modification of previous procedures (Sanes and Hall, 1979; Godfrey et al., 1984). Samples were homogenized in $10 \mathrm{~mm}$ Tris-HCl buffer ( $\mathrm{pH}, 7.4)$ containing $20 \mathrm{U} / \mathrm{ml}$ aprotinin, $5 \mathrm{~mm}$ benzamidine- $\mathrm{HCl}$, $100 \mathrm{~mm}$ 6-aminohexanoic acid, and $0.5 \%$ Triton X-100. The homogenate was centrifuged at $15,000 \times g$ for $15 \mathrm{~min}$ at $4^{\circ} \mathrm{C}$. The pellet was resuspended in the same homogenization medium and centrifuged again. This procedure was repeated 3 times, and the final insoluble pellet was used for the analysis. Tissue from contralateral muscles as well as from nonoperated animals were extracted in parallel as controls.

Aliquots of the resuspended ECM-like material were spotted on dry Whatman 3-mm filter disks impregnated by prior soaking in $2.5 \%$ cetylpyridinium chloride (CPC). The filter disks were washed sequentially in $25 \mathrm{~mm}$ sodium sulfate, distilled water, and $95 \%$ ethanol, then dried for scintillation counting (Rapraeger and Bernfield, 1985).

Proteoglycans were extracted from the final ECM-like pellet as described previously (Brandan and Inestrosa, 1987a). Briefly, the pellet was extracted with $4 \mathrm{M}$ guanidine- $\mathrm{HCl}$, desalted by chromatography on Sephadex G-50 SF, and concentrated by an ion exchange chromatography on a DEAE-Sephacel column. Recovery from the concentration procedure was between 90 and $95 \%$. When ${ }^{35} \mathrm{~S}$ material obtained from the DEAE-Sephacel was incubated with degradative enzymes (see below), the ${ }^{35} \mathrm{~S}$ material was dialyzed against $10 \mathrm{~mm}$ Tris-IICl (pII, 7.4) with $0.1 \mathrm{M} \mathrm{NaCl}$ containing protease inhibitors for $24 \mathrm{hr}$ at $4^{\circ} \mathrm{C}$.

Column chromatography. Sepharose CL-4B and CL-6B $(0.7 \times 120$ $\mathrm{cm}$ ) columns were prepared in $1 \%$ sodium dodecyl sulfate, $0.1 \mathrm{M} \mathrm{NaCl}$, and $50 \mathrm{~mm}$ Tris- $\mathrm{HCl}$ buffer $(\mathrm{pH}, 8.0)$. Samples $(1.0 \mathrm{ml})$ were applied to columns together with previously fractionated Dextran blue 2000 (Pharmacia) and Phenol red to mark the void and total volumes, respectively. Columns were eluted at a flow rate of $2.8 \mathrm{ml} / \mathrm{hr}$. Effluent fractions of $0.8-1.0 \mathrm{ml}$ were collected and analyzed for radioactivity.

Enzymatic treatment and chemical analyses. Chrondroitinase $\mathrm{ABC}$ digestion of ${ }^{35} \mathrm{~S}$-proteoglycans was performed in $50 \mathrm{~mm}$ Tris- $\mathrm{HCl}$ buffer $(\mathrm{pH}, 7.0)$ containing $100 \mathrm{mM} \mathrm{NaCl}$. Digestions were carried out with $0.1 \mathrm{U} / \mathrm{ml}$ of the glycosidases for $5 \mathrm{hr}$ at $37^{\circ} \mathrm{C}$. Degradation of the $\mathrm{HS}$ proteoglycans was performed by nitrous acid treatment using reaction "A" of Lindahl et al. (1973). Aliquots of digested or extracted materials were spotted on CPC filters, and the remaining proteoglycans were quantified. Glycosaminoglycan (GAG) chains were obtained from the proteoglycans by mild alkali treatment $\left(24 \mathrm{hr}\right.$ at $37^{\circ} \mathrm{C}$ in $100 \mathrm{~mm} \mathrm{NaOH}$ and $1 \mathrm{M} \mathrm{NaBH}_{4}$ ). After neutralization, the products were analyzed by chromatography on Sepharose CL-6B.

$S D S-P A G E$ analysis of proteoglycans. Samples eluted from the DEAESephacel column and Sepharose CL-4B were analyzed by electrophoresis on 3-8\% polyacrylamide-dodecyl sulfate gradient gels as previously described (Carlson and Wight, 1987), following by autoradiography and fluorography.

Double-isotope labeling experiment. Animals were injected intraperitoneally with $2 \mathrm{mCi}^{35} \mathrm{~S}$-sulfate (carrier-free) and $3 \mathrm{mCi}{ }^{3} \mathrm{H}$-glucosamine $(30 \mathrm{Ci} / \mathrm{mmol}$ ) in $0.9 \% \mathrm{NaCl}$. Proteoglycans were purified as described above, and the presence of ${ }^{35} \mathrm{~S}$ and ${ }^{3} \mathrm{H}$ was determined after DEAESephacel and Sepharose CL-4B chromatography. The radioactivity of each isotope was measured in a Beckmann LS-100 counter and differentiated by the appropriate window setting and spillover corrections.

Catabolic experiment. Animals denervated $6 \mathrm{~d}$ and control animals were injected with a total of $2 \mathrm{mCi}{ }^{35} \mathrm{~S}$-sulfate in $0.9 \% \mathrm{NaCl}$. Four injections were carried out during $24 \mathrm{hr}$ (every $6 \mathrm{hr}$ ). The amount of ${ }^{35}$ S-labeled ECM material at the end of the pulse and 3, 6, and $12 \mathrm{~d}$ later was determined.

$A C h E$ assay. AChE activity was determined as described by Fadic and Inestrosa (1989) and measured as described by Ellman et al. (1961).

\section{Results}

Denervation increases the synthesis of muscle proteoglycans In initial experiments, we measured the effect of muscle denervation on the incorporation of ${ }^{35} \mathrm{~S}$-sulfate into a detergent-insoluble fraction of muscle homogenates containing ECM. Rat leg muscles were denervated by section of the sciatic nerve and at different times after denervation, the animals were injected intraperitoneally with radioactive sulfate. Six hr later, the leg muscles were removed and homogenized, and a detergent-insoluble fraction was prepared as described in Materials and Methods.

Denervation of muscles for $6 \mathrm{~d}$ produced an approximately 2-fold increase in ${ }^{35} \mathrm{~S}$-sulfate incorporation into the ECM fraction (Table 1). As a positive control for muscle denervation, we also measured AChE activity, which was decreased as expected (Hall, 1973). The increased sulfate incorporation could be seen as early as $1.5 \mathrm{~d}$ after denervation, the carliest time tested, and reached a maximal value approximately $6 \mathrm{~d}$ after denervation (Fig. 1).

To determine if the sulfate incorporated after denervation was associated with proteoglycans, the detergent-insoluble fraction was extracted with guanidinium salts and fractionated by ion-exchange chromatography on DEAE-Sephacel. The percent of incorporated ${ }^{35} \mathrm{~S}$-sulfate that was extracted by this procedure and retained on the column was $85 \%$ for innervated muscle and $87 \%$ for denervated muscle. Although the total amount of radioactivity retained on the column was twice as much for the denervated muscle extract as for the innervated muscle, the column profile was essentially the same in both cases (Fig. 2). Sulfate-labeled macromolecules obtained after DEAE-Sephacel chromatography were totally sensitive to glycosidase treatments (E. Brandan, unpublished observations). These results demonstrate that denervation increased the incorporation of sulfate into ECM proteoglycans.

Increased incorporation of sulfate into proteoglycans could arise from (1) an increase in size of newly synthesized proteoglycans, (2) a change in the length, or (3) degree of sulfation of the GAG chains associated with the proteoglycans, (4) an increase in the rate of proteoglycan synthesis, or (5) a decrease in the degradation ratc of proteoglycans. We have investigated each of these possibilities.

The size of the proteoglycans was estimated by Sepharose C.L4B column chromatography and by SDS-PAGE of the pooled DEAE-Sephacel fractions. Sepharose CL-4B chromatography of innervated and denervated fractions showed similar profiles. In each case, there were 2 major peaks, whose $K_{a v}$ values were 0.21 and 0.50 , respectively (Fig. $3 A$ ). In innervated muscle extracts, the proportion of radioactivity in the 2 peaks was approximately equal, whereas in denervated muscle, the smaller fraction showed a slight predominance. The increased incorporation in denervated muscles therefore cannot be explained by an increase in molecular size of the newly synthesized proteoglycans. SDSPAGE confirmed the presence of sulfated proteoglycans of 2 different sizes. (Fig. $3 B$ ). The $M_{r}$ calculated by mobility in an SDS-PAGE gradient gel was $110-80 \mathrm{kDa}$ for the smallest, whereas the largest has a very high molecular weight.

GAG chain length was measured after isolation from the proteoglycans by mild alkaline treatment. Sepharose CL-6B chromatography of the released GAG chains showed a similar pattern in each case (Fig. 4), indicating that increased GAG chain length is not responsible for the increased sulfate incorporation seen in denervated muscle. 
Table 1. Effect of denervation on ${ }^{35} \mathrm{~S}$ incorporation in ECM macromolecules and $\mathrm{AChE}$ activity of rat leg skeletal muscles

\begin{tabular}{lllll} 
& $\begin{array}{l}{ }^{35} \text { S incorporation in } \\
\text { proteoglycans (cpm/gm) }\end{array}$ & \multicolumn{3}{c}{ Total AChE activity } \\
\cline { 5 - 5 } & $20.700 \pm 1460(4)$ & 100 & U/gm & \% \\
\hline Normal muscle & $19.200 \pm 2800(6)$ & 93 & $1.93 \pm 0.07(9)$ & 100 \\
Contralateral muscle & $41.900 \pm 2980(6)$ & 202 & $0.66 \pm 0.09(4)$ & 35
\end{tabular}

ECM-like material was prepared from normal (nonoperated), contralateral and denervated (6 d) leg skeletal muscles from rats previously injected with $1 \mathrm{mCi}{ }^{35} \mathrm{~S}$ for $6 \mathrm{hr}$. Dencrvated muscle weight fall $19.8 \pm 2.1 \%$. Aliquots were spottcd on CPC-impregnated filter disks, which quantitatively bind GAG-containing material (Rapraeger and Bernfield, 1985; Brandan and Inestrosa, 1987a). Then, the disks were processed and counted for radioactivity. Each value represents the mean \pm SEM of $(n)$

To determine whether or not a change in the degree of GAG sulfation occurs after denervation, rats were injected with a mixture of ${ }^{35} \mathrm{~S}$-sulfate and ${ }^{3} \mathrm{H}$-glucosamine. Proteoglycans were prepared from ECM-rich fractions from control and denervated muscles by guanidinium extractions and chromatography on DEAE-Sephacel, and the amount of each label was determined. Denervation produced an increase of approximately 3 -fold in incorporation of both ${ }^{3} \mathrm{H}$-glucosamine and ${ }^{35} \mathrm{~S}$-sulfate. The ${ }^{35} \mathrm{~S}$ : ${ }^{3} \mathrm{H}$ ratio was identical in both fractions (Table 2 ), suggesting a comparable degree of GAG sulfation in innervated and denervated muscles. Fractionation of ${ }^{3} \mathrm{H}$ - and ${ }^{35} \mathrm{~S}$-labeled macromolecules through Sepharose CL-4B indicates that both isotopes are present in the same proteoglycan (Fig. $3 A$, inset).

Taken together, the experiments characterizing the proteoglycans in innervated and denervated muscle show no differences between them that would explain the increased incorporation of label that occurs after denervation.

The final possibility is that denervation results in a decreased catabolic rate of ECM proteoglycans, thus increasing the incorporation of ${ }^{35} \mathrm{~S}$-sulfate. To measure the rate of degradation, proteoglycans were labeled by injecting animals with radioactive

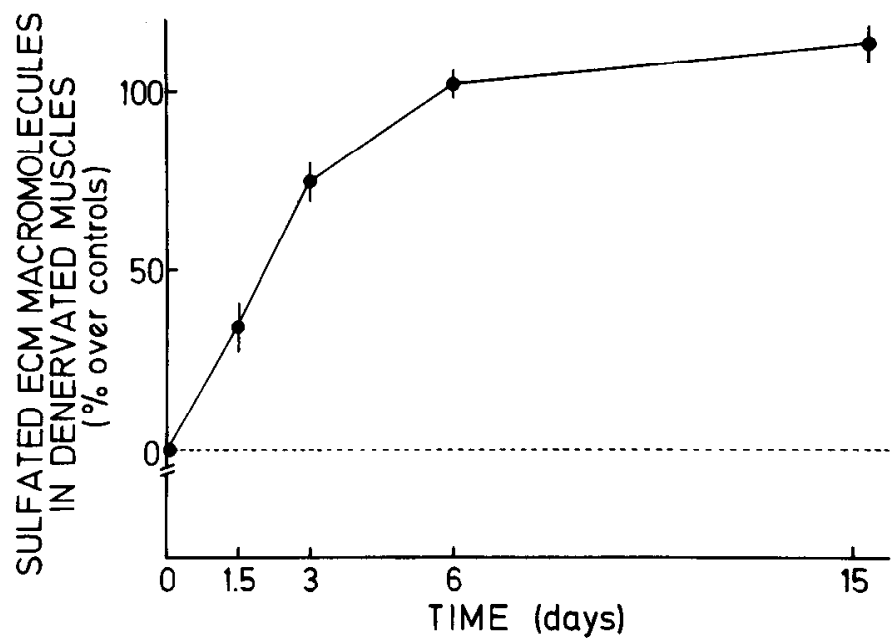

Figure 1. Time course of ${ }^{35} \mathrm{~S}$ incorporation in muscle ECM macromolecules after denervation. Experiments were carried out on leg muscles of male Srague-Dawley rats. Muscles were denervated under Nembutal anesthesia by removal of a $1-\mathrm{cm}$ segment of the sciatic nerve. At different times thereafter, denervated and control rats were injected intraperitoneally with ${ }^{35} \mathrm{~S}$ in saline for $6 \mathrm{hr}$. ${ }^{35} \mathrm{~S}$ present in ECM macromolecules was measured as described in Materials and Methods. Muscle weight decreased $5.2 \pm 3.1,12.3 \pm 2.9,19.8 \pm 2.1$, and $34.6 \pm$ $4.4 \% \pm$ SEM at $1.5,3,6$, and $12 \mathrm{~d}$, respectively, after nerve section. Values are mean \pm SEM of 6 experiments expressed as percentage of controls. sulfate. Twenty-four hr later, unlabeled sulfate was injected, and muscles were taken at various times thereafter, and the amount of radioactivity remaining in the detergent insoluble fraction was determined. The half-time of loss of radioactivity was the same in innervated and in denervated muscles: 4-5 d (Fig. 5). We conclude that there is no change in the rate of proteoglycan degradation after denervation, and that the change in incorporation must represent a change in synthesis or insertion of proteoglycans, leading to their accumulation in the ECM.

The ECM fraction of adult rat muscle contains several types of proteoglycans (Brandan and Inestrosa, 1987a). We examined the sensitivity of the proteoglycans to nitrous acid and to chondroitinase $A B C$ treatment in order to determine whether all classes of proteoglycans were equally affected by denervation. There was $43 \% \mathrm{HS}$ and $57 \%$ CS/DS proteoglycan in control muscles, confirming previous results (Brandan and Inestrosa, 1987a). We found that, though incorporation into both HS and CS/DS proteoglycans was increased after $6 \mathrm{~d}$ of denervation, the increase was significantly greater for proteoglycans of the CS/DS type (Table 3 ).

\section{Muscle activity regulates the expression of ECM proteoglycans}

Many properties of muscle fibers are altered by denervation and restored to their original state when the muscle is reinnervated. The same is true for proteoglycan synthesis as measured by ${ }^{35} \mathrm{~S}$ sulfate incorporation. When muscles were denervated by crushing the nerve, rather than by nerve section, and examined $30 \mathrm{~d}$ later, when reinnervation is known to have occurred (Fadic and Inestrosa, 1989), the level of incorporation of ${ }^{35} \mathrm{~S}$-sulfate was identical to that of normally innervated muscle (Fig. 6). Incorporation thus appears to be neurally regulated.

One effect of denervation and reinnervation is to change muscle activity. Neurally induced muscle activity is know to regulate the level of a number of cell surface molecules, including AChR (Lomo and Rosenthal, 1972; Goldman et al., 1988), AChE (Lømo et al., 1985), and N-CAM (Covault and Sanes, 1985). To test the idea that muscle activity controls the level of proteoglycans in the muscle ECM, we paralyzed innervated muscles in 2 ways: by repeated local aplications of TTX (Pestronk et al., 1977) and by tenotomy. In both cases, wc obscrved an increase in ${ }^{35} \mathrm{~S}$ sulfate incorporation into the ECM fraction comparable to that observed in denervated muscles (Fig. 6). These results suggest that it is the state of muscle activity that regulates the level of proteoglycans in muscle.

\section{Discussion}

There is no information about the regulation of ECM proteoglycan expression in muscle fibers in vivo. Recently, attention 


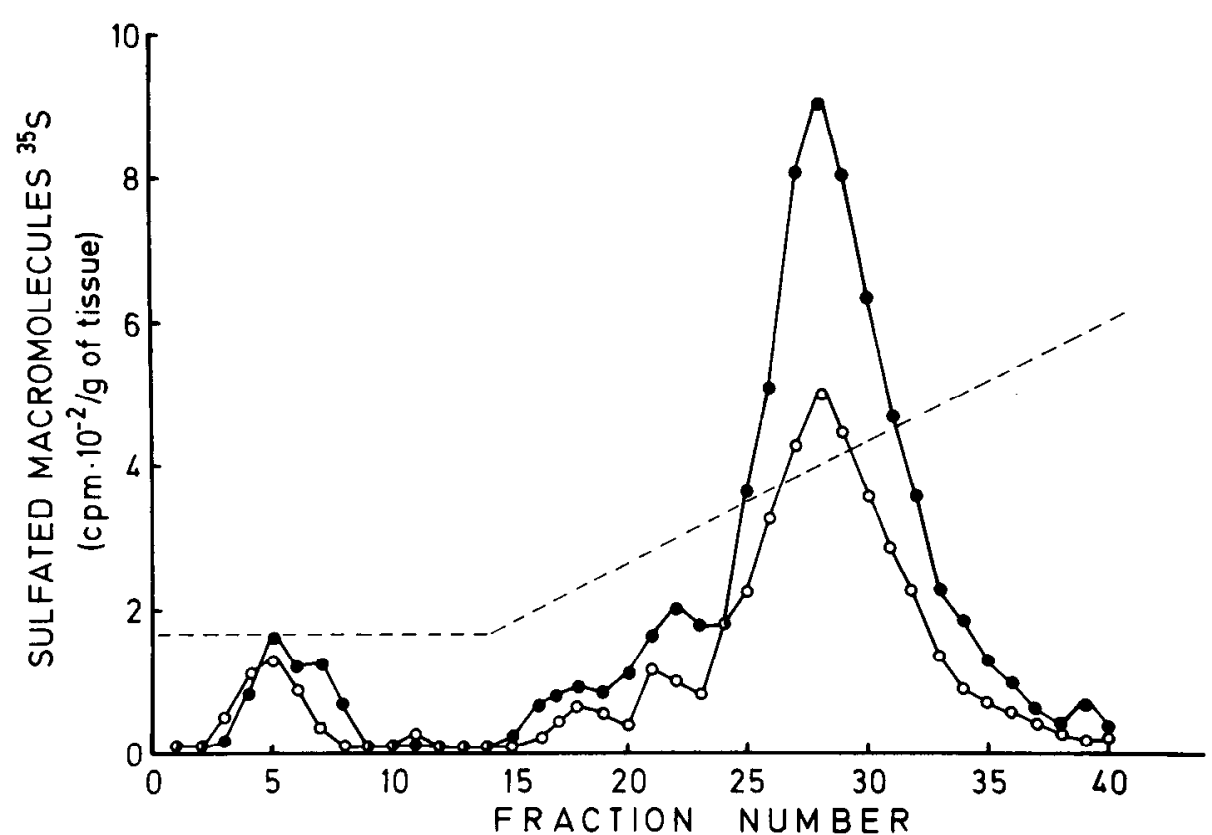

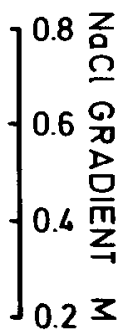

Figure 2. Effect of denervation on "ss incorporation in muscle ECM proteoglycans. The solid curves are DEAE-Sephacel profiles of an equal amount of ECM-like material from 6-d denervated (solid circles) and control-innervated (open circles) leg skeletal muscles of rats injected with ${ }^{35} \mathrm{~S}$ for $6 \mathrm{hr}$ (see Materials and Methods for details). The dashed curve indicates the $\mathrm{NaCl}$ gradient profile. The recovery from both columns ranged from 88 to $91 \%$. has been focused on the identification of factors that could guide axons during reinnervation of skeletal muscles (Covault and Sanes, 1985; Chiu et al., 1986; Sanes et al., 1986; Bixby et al., 1987; Sanes, 1989). It has been proposed that denervated muscles use cell-surface and ECM molecules to influence the behavior of regenerating axons (Covault et al., 1987; Hunter et al., 1989). In this context, it was of interest to us to examine the effect of denervation on the expression of proteoglycans in muscle ECM.

In the present study, we found that motor nerves regulate the expression of muscle ECM proteoglycans. The control of muscle proteoglycans seems to be related to the nerve-induced muscle activity. Our experiments showed an increase in ${ }^{35} \mathrm{~S}$ incorporation into ECM protcoglycans after denervation. Several lines of evidence suggest that the increase observed in sulfate incorporation into proteoglycans corresponds to an increse in the synthesis of these macromolecules rather than to changes in proteoglycan size, GAG chain length, degree of sulfation of GAGs, or catabolic rate. Reinnervation results in reversal to the normal situation. Thus, the level of muscle proteoglycans is controlled by innervating motor nerves.

It has recently been reported that transforming growth factor $\beta$ (TGF- $\beta$ ) increases the expression of proteoglycans released into the medium and incorporated into the matrix of mesenchymal and epithelial cells in culture (Bassols and Massagué, 1988). TGF- $\beta$ acts at 2 levels: it increases the molecular mass of proteoglycans by increasing GAG chain length, and it elevates the biosynthetic rate of proteoglycan core protein (Bassols and Massagué, 1988). TGF- $\beta$ also stimulates the synthesis of proteoglycans in bovine cartilage organ cultures, as well as decreasing their rates of catabolism (Morales and Roberts, 1988). The GAGs regulated by TGF- $\beta$ correspond to the CS/DS type, as shown in kidney fibroblasts (Bassols and Massagué, 1988) and human smooth muscle cells (Chen et al., 1987) and for the hybrid cell-surface proteoglycan of mammary epithelial cells (Rasmussen and Rapraeger, 1988). We did not detect any change in GAG chain length or molecular mass of proteoglycans in denervated muscle; neither did we detect a change in their cat- abolic rate. Interestingly, we found that CS/DS proteoglycans present a greater increase than the HS type. These results show that the nerve control of the proteoglycan expression in the muscle has similarities and differences with the TGF- $\beta$ effect on the proteoglycans of cultured cells.

Muscle inactivity mimics denervation in that induces terminal sprouting (Brown et al., 1981), renders muscle fibers susceptible to hyperinnervation (Grinell and Herrera, 1981), and increases the level of cell-surface macromolecules such as the extrajunctional AChR (Pestronk et al., 1977) and N-CAM (Covault and Sanes, 1985). We induced muscle inactivity without denervation (by tenotomy or blockade of nerve conduction by TTX) to determine whether muscle activity was responsible for the increased incorporation of ${ }^{35} \mathrm{~S}$-sulfate seen after denervation. The increase in ECM proteoglycans found in paralyzed muscles was similar to that observed after denervation. Therefore, proteoglycan expression appears to be controlled primarily by nerveevoked muscle activity. Interestingly enough, it has been reported that the collagen accumulation that occurs in inactive muscles can be prevented by active stimulation (Williams et al., 1988). In addition, the expression of a surface-associated CS proteoglycan of the mammalian CNS recently has been shown to be regulated by neuronal activity (Zaremba et al., 1989).

The increase observed in muscle proteoglycans with denervation or muscle paralysis, which is restored to normal level after reinnervation, seems to be common to various musclefiber cell-surface macromolecules, such as AChR and N-CAM. It has been reported recently that muscle activity decreases the level of mRNA coding for AChR subunits, suggesting that muscle activity controls the transcription of the $\Lambda$ ChR genes (Goldman et al., 1988). This pattern could be a general one for most cell-surface macromolecules. Nerve-evoked muscle activity could be regulating the muscle-cell surface composition through a coordinate influence of the expression of several macromolecules.

The changes in ECM after denervation possibly modulate the behavior of regenerating axons. It has been proposed that denervated or inactive muscles secrete a soluble factor that promotes axonal growth (Henderson et al., 1983; Sanes, 1989). On 


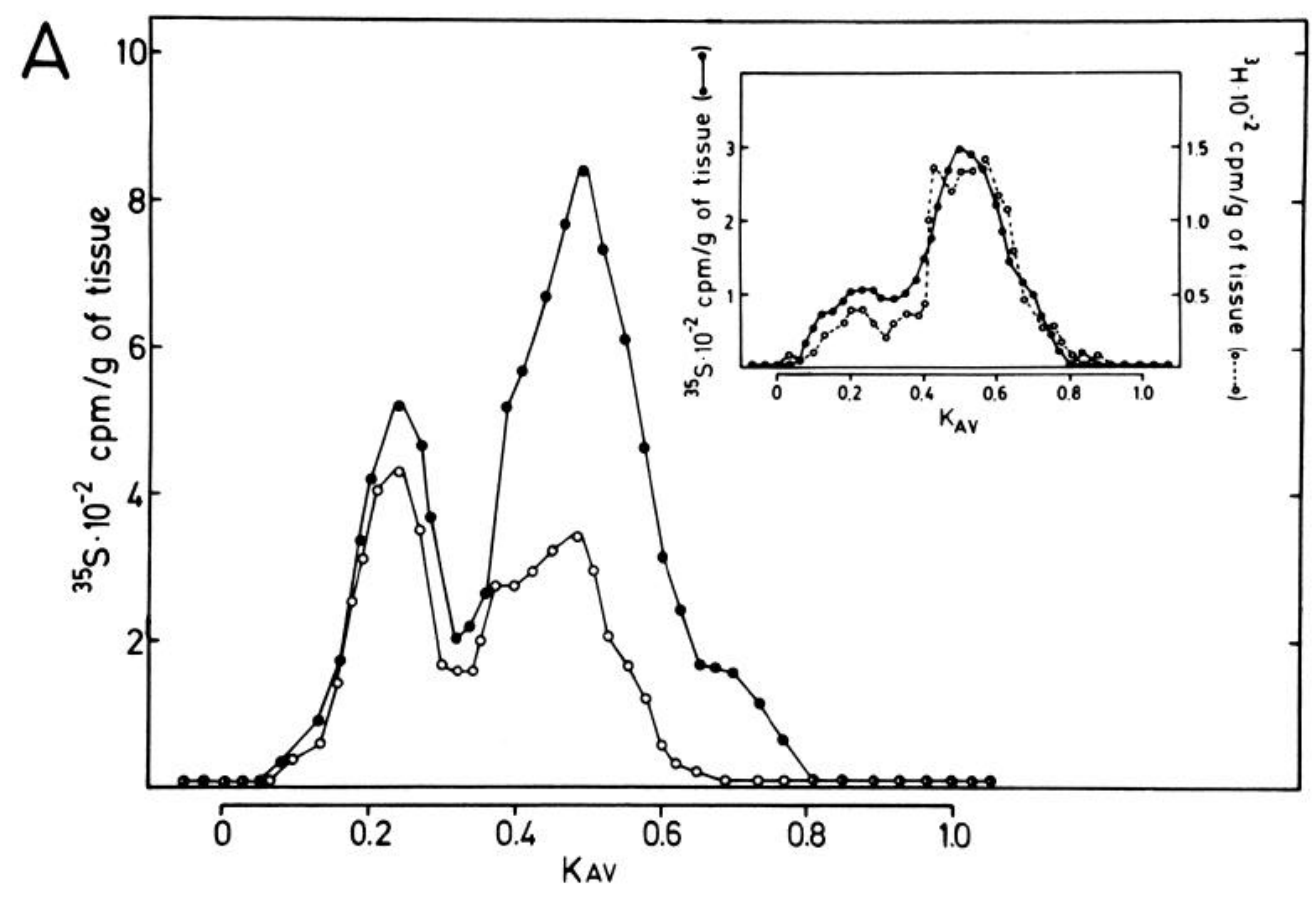

Figure 3. Effect of denervation on hydrodynamic size of muscle proteoglycans. $A$, Sepharose CL-4B profile of proteoglycans eluted from DEAE-Sephacel columns. There is no size change in proteoglycans from denervated muscles (solid circles) as compared with normal muscles (open circles). B, Sulfated proteoglycan samples eluted from DEAE-Sephacel columns (lane 1 ) and from Sepharose CL-4B with a $K_{a v}$ of 0.21 (lane 2) and 0.50 (lane 3) were analyzed by electrophoresis on 3-8\% SDS polyacrilamide gels and fluorography. The arrow indicates sulfated proteoglycan with a $K_{a v}$ of 0.21 , and the arrowhead indicates proteoglycans with a $K_{a v}$ of 0.50 . Inset, Clearly, ${ }^{35} \mathrm{~S}$ and ${ }^{3} \mathrm{H}$ labels were incorporated to the same macromolecules, as indicated in the Sepharose CL-4B profile after DEAE-Sephacel chromatography. Animals received $1 \mathrm{mCi}$ of each radioisotope.

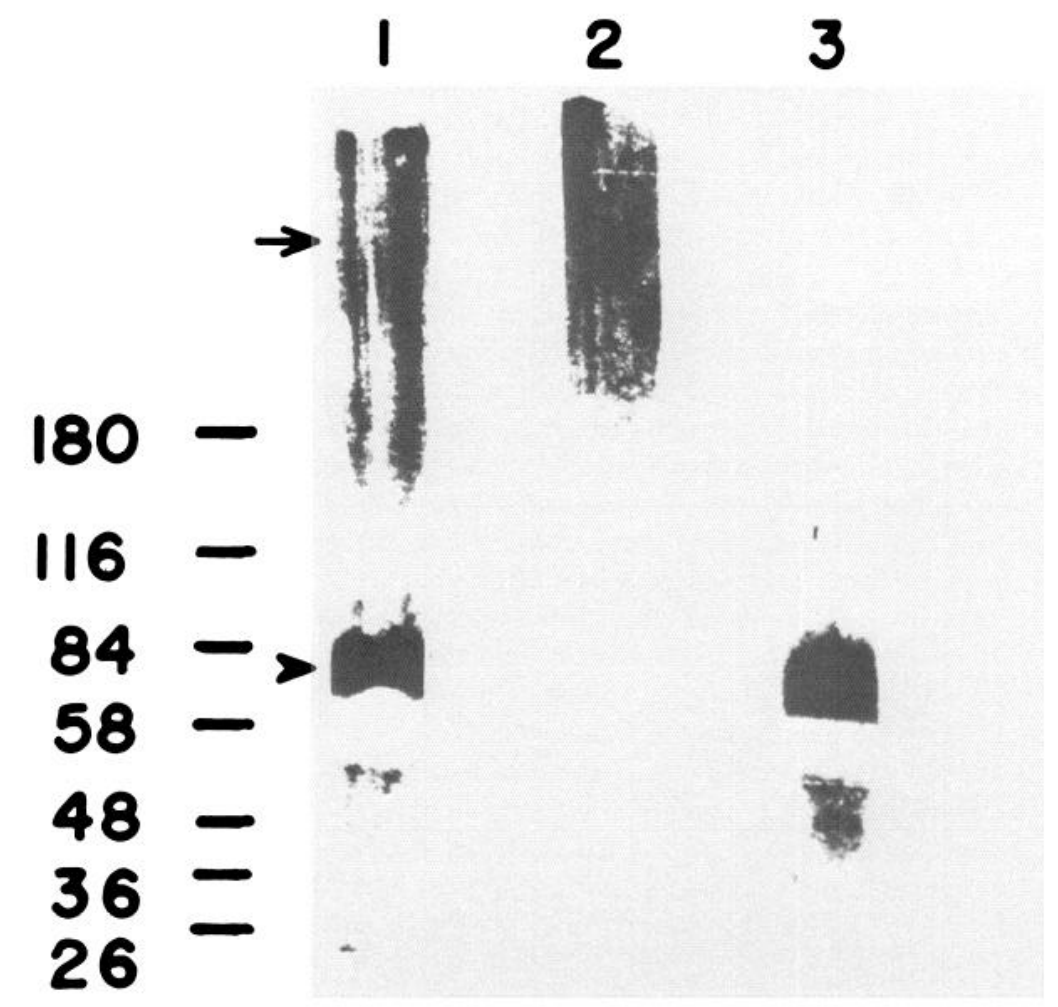

the other hand, Sanes (1989) has proposed the hypothesis that the denervation-induced changes in the muscle-fiber surface are used to inform regenerating axons of their state of innervation and proximity to synaptic sites. Ciliary ganglion neurons extend neurites on muscle sections in vitro, generally in close apposition to sectioned cell surfaces (Covault et al., 1987). Average neurite length was greater on sections of denervated than on sections of innervated muscle, supporting the idea that functionally im-

portant differences exist between innervated and denervated muscle-fiber surfaces. ECM proteoglycans have been implicated in neurite growth-promoting activity (Lander et al., 1982, 1985), support of axonal regeneration (Chiu et al., 1986; Sanes et al., 1986), adhesion of retinal neurones to an extracellular substrate (Cole et al., 1985, 1986), and as an anchorage site for the asymmetric AChE (Brandan et al., 1985; Inestrosa and Perelman, 1989). Thus, the increase in ECM proteoglycans after dener- 


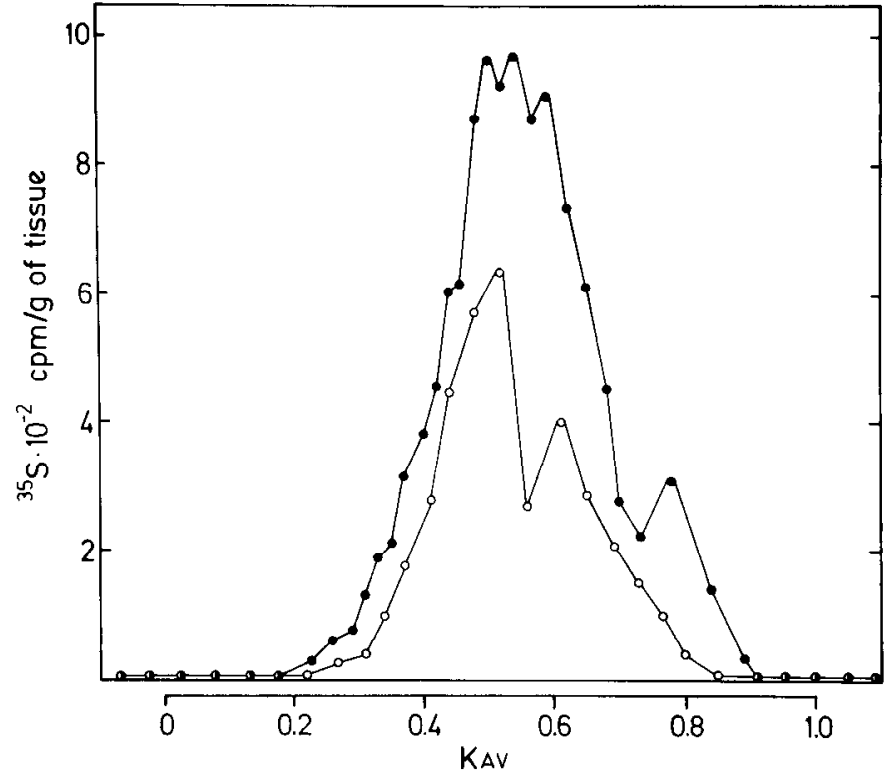

Figure 4. Glycosaminoglycan chain length of proteoglycans from denervated and innervated muscles. The curves show Sepharose CL-6B elution profiles of alkaline-treated ECM from denervated (solid circles) and innervated (open circles) rat skeletal muscles (see Materials and Methods for more details).

vation observed in the present study could contribute to the axonal regeneration process, possibly by facilitating axonal growth.

Studies using immunocytochemical methods, aiming to compare levels of several adhesive macromolecules in denervated and innervated skeletal muscles, have revealed that the expression of laminin, fibronectin, and HS protenglycans change little after denervation (Sanes et al., 1986). On the contrary, we observed a clear increase in ECM proteoglycans after muscle denervation. This apparent discrepancy could be explained because the antibody used in the above observation recognizes only the HS proteoglycan. On the contrary, we found that the main change produced by denervation was in the CS/DS proteoglycan expression. Recently, it has been shown that some of the ECM components present in the muscle at synaptic sites are synthesized by fibroblasts (Gatchalian et al., 1989). Moreover, muscle fibroblasts proliferate after denervation (Connors and McMahan, 1987; Gatchalian et al., 1989). The precise cell type responsible for the increase in proteoglycan synthesis reported here requires further attention.

In conclusion, the results reported here are the first biochem-

Table 2. Effect of denervation on ${ }^{35} \mathrm{~S}$-sulfate and ${ }^{3} \mathrm{H}$-glucosamine incorporation in ECM proteoglycans of rat leg skeletal muscles

\begin{tabular}{lll} 
& $\begin{array}{l}\text { Control } \\
(\mathrm{cpm} / \mathrm{gm})\end{array}$ & $\begin{array}{l}\text { Denervated } \\
(\mathrm{cpm} / \mathrm{gm})\end{array}$ \\
\hline${ }^{35} \mathrm{~S}$ & 6438 & 20,108 \\
${ }^{3} \mathrm{H}$ & 6109 & 18,619
\end{tabular}
${ }^{35} \mathrm{~S}:{ }^{3} \mathrm{H}$
1.04
1.08

Normal and 6-d denervated rats were injected with ${ }^{35} \mathrm{~S}$-sulfate and ${ }^{35} \mathrm{H}$-glucosamine for $6 \mathrm{hr}$. ECM-like material was prepared as described in Materials and Methods. The labeled ECM proteoglycans, from an equal amount of ECM-like material, were solubilized by guanidine and applied to DEAE-Sephacel column. ${ }^{35} \mathrm{~S}$ and ${ }^{3} \mathrm{H}$ radioactivity were measured in the bound material, which was eluted with $0.8 \mathrm{M}$ $\mathrm{NaCl}$ in column buffer.

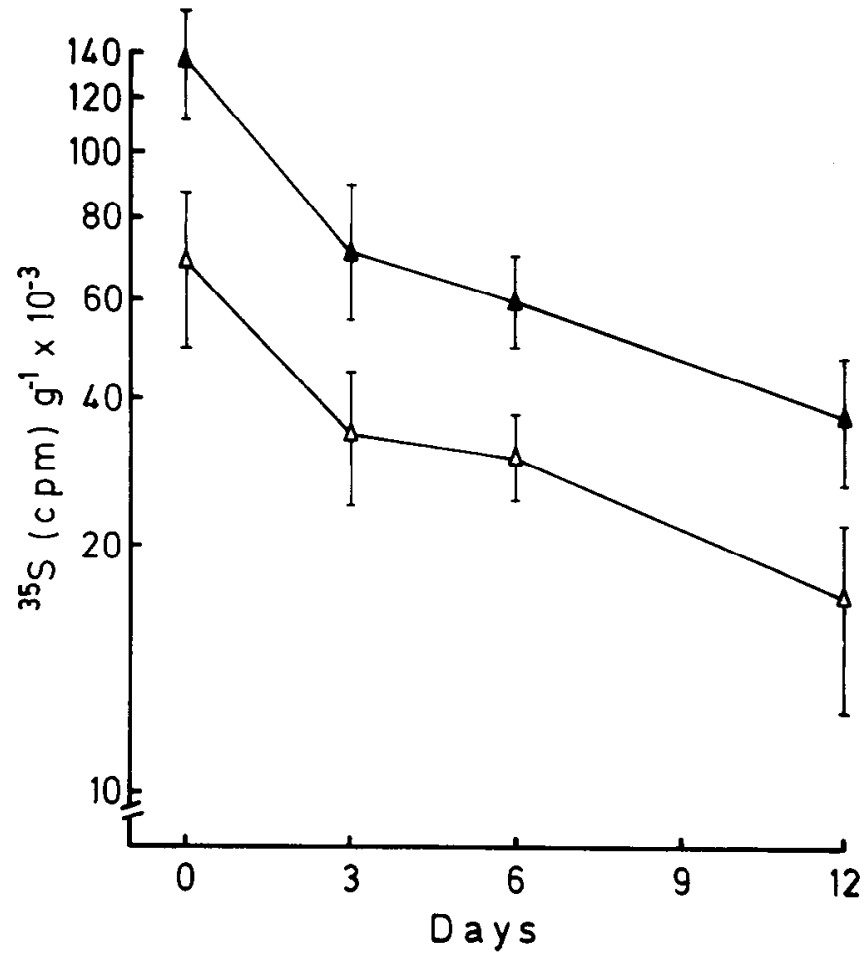

Figure 5. Effect of denervation on ECM proteoglycans catabolism. Six $\mathrm{d}$ denervated rats (solid triangles) and controls (open triangles) were injected with ${ }^{35} \mathrm{~S}$ during a $24-\mathrm{hr}$ period. The amount of ${ }^{35} \mathrm{~S}$-labeled ECM material at the end of the pulse and 3,6, and $12 \mathrm{~d}$ after dencrvation was determined. Values are mean $\pm \operatorname{SEM}(n=4)$.

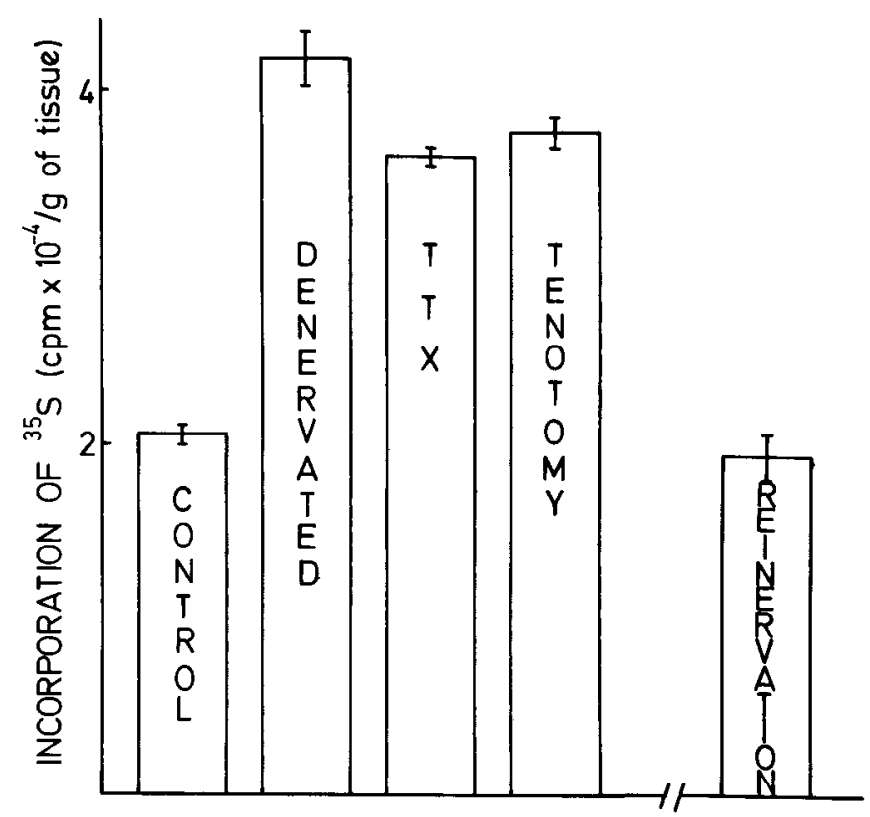

Figure 6. Effect of muscle activity on ${ }^{35} \mathrm{~S}$ incorporation in ECM proteoglycans. Leg muscles paralyzed for $6 \mathrm{~d}$ were obtained by complete blockade of sciatic nerve conduction by repeated local applications of TTX (Pestronk et al., 1977) or by tenotomy (see Materials and Methods for details). Denervated muscles are also shown for comparison. In the nerve regeneration experiments, muscles were denervated by crushing the sciatic nerve. Samples were obtained $30 \mathrm{~d}$ after paralysis (Fadic and Inestrosa, 1989). Each column represents the mean \pm SEM of 4-6 experiments. 
Table 3. Effect of denervation on ${ }^{35} \mathrm{~S}$ incorporation on different types of muscle ECM proteoglycans

\begin{tabular}{lclr} 
Proteoglycan type & $\begin{array}{l}\text { Control } \\
\text { (cpm/gm) }\end{array}$ & $\begin{array}{l}\text { Denervated } \\
\text { (cpm/gm) }\end{array}$ & \multicolumn{1}{c}{$\begin{array}{l}\text { Increase } \\
(\%)\end{array}$} \\
\hline Heparan sulfate & $7720 \pm 659(14)$ & $12,940 \pm 1335(14)$ & 67 \\
Chondroitin/dermatan & $10,230 \pm 982(14)$ & $26,060 \pm 2536(14)$ & 155
\end{tabular}

An equal amount of ECM-like material was prepared from normal and 6-d denervated muscles. ECM-labeled proteoglycans were incubated with chondroitinase ABC and nitrous acid to determine the presence of CS/DS and HS proteoglycans, respectively. The values are the mean \pm SEM of $(n)$ experiments.

ical evidence of an increase in ECM proteoglycans following denervation. They indicate that the motor nerve regulates the expression of muscle ECM by the evoked muscle activity.

\section{References}

Bassols A, Massagué J (1988) Transforming growth factor $\beta$ regulates the expression and structure of extracellular matrix chondroitin/dermatan sulfate proteoglycans. J Biol Chem 263:3039-3045.

Berman P, Gray P, Chen E, Keyser K, Ehrlich D, Karten H, La Corbiere M, Esch F, Schubert D (1987) Sequence analysis, cellular localization, and expression of a neuriretina adhesion and cell survival molecule. Cell 5:135-142.

Bixby JL, Pratt RS, Lilien J, Reichardt LF (1987) Neurite outgrowth on muscle cell surfaces involved extracellular matrix receptors as well as $\mathrm{Ca}^{2+}$-dependent and -independent cell adhesion molecules. Proc Natl Acad Sci USA 84:2555-2559.

Brandan E, Inestrosa NC (1987a) Isolation of the heparan sulfate protenglycans from the extracellular matrix of rat skeletal muscle. J Neurobiol 18:271-282.

Brandan E, Inestrosa NC (1987b) Co-solubilization of asymmetric acetylcholinesterase and dermatan sulfate proteoglycan from extracellular matrix of rat skeletal muscles. FEBS Lett 213:159-163.

Brandan E, Maldonado M, Garrido J, Inestrosa NC (1985) Anchorage of collagen-tailed acetylcholinesterase to the extracellular matrix of rat skeletal muscles. J Cell Biol 101:985-992.

Brown MC, Holland LR, Hoplins WG (1981) Motor nerve sprouting. Annu Rev Neurosci 4: 17-42.

Carlson SS, Wight TN (1987) Nerve terminal anchorage protein 1 (TAP-1) is a chondroitin sulfate proteoglycan biochemical and electron microscopic characterization. J Cell Biol 105:3075-3086.

Chen JK, Hoshi EC, McKeehan WL (1987) Transforming growth factor type B specifically stimulates synthesis of proteoglycan in human muscle cells. Proc Natl Acad Sci USA 84:5287-5291.

Chiu AY, Matthew WD, Patterson PH (1986) A monoclonal antibody which blocks the activity of a neurite regeneration promoting factor: studies on the binding site and its localization in vivo. J Cell Biol 102: 1383-1398.

Cole GJ, Schubert D, Glaser L (1985) Cell-substratum adhesion in chick neural retina depends on protein-heparan sulfate interactions. J Cell Biol 100:1 192-1199.

Cole GJ, Loewy A, Glaser L (1986) Neuronal cell-cell adhesion depends on interactions of N-CAM with heparin-like molecules. Nature 320:445-447.

Connors AE, McMahan UJ (1987) Cell accumulation in the junctional region of denervated muscle. J Cell Biol 104:109-120.

Covault J, Sanes JR (1985) Neural cell adhesion molecule (N-CAM) accumulates in denervated and paralysed skeletal muscle. Proc Natl Acad Sci USA. 82:4544-4548.

Covault J, Cunningham JM, Sanes JR (1987) Neurite outgrowth on cryostat sections of innervated and denervated skeletal muscle. J Cell Biol 105:2479-2488.

Ellman GL, Courtney KD, Andres V Jr, Fcatherstonc RM (1961) A new and rapid colorimetric determination of acetylcholinesterase activity. Biochem Pharmacol 7:1463-1468.

Fadic R, Inestrosa NC (1989) Nerve regulation of class I and class IIasymmetric forms of acetylcholinesterase in rat skeletal muscles. J Neurosci Res 22:449-455.

Gatchalian CL, Schachner M, Sanes JR (1989) Fibroblast that proliferate near denervated synaptic sites in skeletal muscle synthesize the adhesive molecules tenascin (J1), N-CAM, fibronectin, and heparan sulfate proteoglycan. J Cell Biol 108:1873-1890.

Godfrey EW, Siebenlist RE, Wallskog PA, Walters LM, Bolender DL,
Yorde DE (1988) Basal lamina components are concentrated in premuscle masses and at early acetylcholine receptor clusters in chick embryo hindlimb muscles. Dev Biol 130:471-486.

Goldman D, Brenner HR, Heinemann S (1988) Acetylcholine receptor $\alpha-, \beta-, \gamma-, \delta$-subunit mRNA levels are regulated by muscle activity. Neuron 1:329-333.

Grinnel AD, Herrera A (1981) Specifity and plasticity of neuromuscular connections: long-term regulation of motoneuron function. Prog Neurobiol 17:203-282.

Hall ZW (1973) Multiple forms of acetylcholinesterase and their distribution in endplate and non-endplate regions of rat diaphragm muscle. J Neurobiol 4:343-361.

Hascall VC, Hascall GK (1981) Proteoglycans in: Cell biology of the extracellular matrix (Hay ED, ed), pp 39-69. New York: Plenum.

Henderson CE, Huchet M, Changeux JP (1983) Denervation increase a neurite-promoting activity in extracts of skeletal muscle. Nature 302:609-611.

Höök M, Kjellen L, Johansson S, Robinson J (1984) Cell surface glycosaminoglycans. Annu Rev Biochem 53:847-869.

Hunter DD, Shah V, Merlie JP, Sanes JR (1989) A laminin-like adhesive protein concentrated in the synaptic cleft of the neuromuscular junction. Nature 338:229-234.

Inestrosa NC, Perelman A (1989) Distribution and anchoring of molecular forms of acetylcholinesterase. Trends Pharmacol. Sci 10:325329.

Lander AD, Fujii DK, Gospodarowicz D, Reichardt LF (1982) Characterization of a factor which promotes neurite outgrowth: evidence linking activity to a heparan sulfate proteoglycan. J Cell Biol 94:574 585 .

Lander AD, Fujii DK, Reichardt LF (1985) Purification of a factor that promotes neurite outgrowth: isolation of a laminin and associated molecules. J Cell Biol 101:898-913.

Lindhal U, Backstrom G, Jansson L, Hallén A (1973) Biosynthesis of heparin. II. Formation of sulfamino groups. J Biol Chem 251:65136521 .

Lomo T, Rosenthal J (1972) Control of ACh sensitivity by muscle activity in the rat. J Physiol (Lond) 221:493-513.

Lømo T, Massoulie J, Vigny M (1985) Stimulation of denervated rat soleus muscle with fast and slow activity patterns induces different expression of acetylcholinesterase molecular forms. J Neurosci 5:11801187.

Merlie JP, Isenberg IE, Russel SD, Sanes JR (1984) Denervation supersensitivity in skeletal muscle: analysis with a cloned cDNA probe. J Cell Biol 99:332-335.

Morales TI, Roberts AB (1988) Transforming growth factor $\beta$ regulates the metabolism of proteoglycans in bovine cartilage organ cultures J Biol Chem 263:; 12828-12831.

Pestronk A, Drachman DB, Griffin JW (1977) Effect of muscle disuse on acetylcholine receptors. Nature 260:352-353.

Rapraeger AC, Berntield M (1985) Cell surface proteoglycan of mammary epithelial cells. J Biol Chem 260:4103-4109.

Rasmussen S, Rapraeger A (1988) Altered structure of the hybrid cell surface proteoglycan of mammary cells in response to transforming growth factor- $\beta$. J Cell Biol 107:1959-1967.

Ratner N, Ilong D, Lieberman MA, Bunge R, Glaser L (1988) The neuronal cell surface mitogenic for Schwann cells is a heparin-binding protein. Proc Natl Acad Sci (USA) 85:6992-6996.

Reiness GC, Hall ZW (1977) Electrical stimulus of denervated muscles reduces incorporation of methionine into the $\mathrm{ACh}$ receptor. Nature 268:655-657.

Rieger F, Grumet M, Edelman GM (1985) N-CAM at the vertebrate neuromuscular junction. J Cell Biol 101:285-293. 
Ruoslathi E (1988) Structure and biology of proteoglycans. Annu Rev Cell Biol 4:229-255.

Sanes JR (1989) Extracellular matrix molecules that influence neural development. Annu Rev Neurosci 12:521-546.

Sanes JR, Hall ZW (1979) Antibodies that bind specifically to synaptic sites on muscle fiber basal lamina. J Cell Biol 83:357-370.

Sancs JR, Marshall LM, McMahan UJ (1978) Reinnervation of muscle fiber basal lamina after removal of miofibres. Differentiation of regenerating axons at original synaptic sites. J Cell Biol 78:176-198.

Sanes JR, Schachner M, Covault J (1986) Expression of several adhesive macromolecules (N-CAM, L1, NILE, uvomorulin, laminin, fibronectin, and a heparan sulfate proteoglycan) in embryonic, adult, and denervated skeletal muscle. J Cell Biol 102:420-431.

Schubert D, LaCorbiere M (1985) Isolation of an adhesion-mediating protein from chick neural retin adherons. J Cell Biol 101:1071-1077.
Schubert D, LaCorbiere M, Esch F (1986) A chick neural retina ad hesion and survival molecule is a retinol-binding protein. $\mathrm{J}$ Cell Biol 102:2295-2301

Shieh BH, Ballivet M, Schmidt J (1987) Quantitation of an alpha subunit splicing intermediate: evidence for transcriptional activation in the control of acetylcholine receptor expression in denervated chick skeletal muscle. J Cell Biol 104:1337-1341.

Williams PE, Catanese T, Lucey EG, Goldspink G (1988) The importance of the stretch and contractile activity in the prevention of connective tissue accumulation in muscle. J Anat 158:109-114.

Zaremba S, Guimaraes A, Kalb RG, Hockfield S (1989) Characterization of an activity-dependent, neuronal surface proteoglycan identified with monoclonal antibody Cat-301. Neuron 2:1207-1219. 